\title{
PENGONTROLAN PINTU PAGAR OTOMATIS MENGGUNAKAN ANDROID
}

\author{
Irwan Yusti \\ Sistem Informasi, Sekolah Tinggi Teknologi Industri Padang \\ email: irwanyusti@gmail.com
}

\begin{abstract}
Abstrak
Abstrak: Setiap manusia membutuhkan rasa aman baik secara fisik maupun psikis, rasa aman hanya akan didapat jika manusia melindungi dirinya dari semua bentuk ancaman yang mungkin terjadi. Penelitian ini bertujuan untuk melindungi manusia dari ancaman fisik maupun psikis yang disebabkan oleh manusia ataupun oleh binatang dengan cara mengoptimalkan kinerja buka tutup pintu pagar menggunakan mikrokontroler dan Android dengan komunikasi berbasis Bluetooth. Metoda yang digunakan pada penelitian ini adalah penelitian terapan dengan tiga langkah yaitu perancangan, ujicoba dan implementasi. Dari hasi implementasi dapat diketahui bahwa pintu pagar dapat dikendalikan dari jarak 25 meter dan hanya dapat dibuka oleh orang yang punya akses untuk itu.
\end{abstract}

Kata kunci: rasa aman, pintu pagar, mikrokontroler dan Android, Bluetooth

Abstract: Every human being needs a sense of security both physically and psychologically, a sense of security will only be obtained if humans protect themselves from all forms of threats that may occur. This study aims to protect humans from physical and psychological threats caused by humans or animals by optimizing the performance of opening and closing the gate using a microcontroller and Android with Bluetooth-based communication. The method used in this research is applied research with three steps, namely design, testing and implementation. From the implementation results, it can be seen that the gate can be controlled from a distance of 25 meters and can only be opened by people who have access to it.

Keywords: security, gate, microcontroller and Android, Bluetooth

\section{PENDAHULUAN}

Setiap manusia membutuhkan rasa aman baik secara fisik maupun secara psikis, rasa aman secara fisik bisa dalam bentuk stabilitas, tindakan kriminal, penyakit, terorisme sedangkan rasa aman psikis bisa dalam bentuk di bully, di rendahkan dan stres, hal tersebut dikemukakan oleh A. H. Maslow (1943). Rasa aman secara fisik cendrung lebih mudah untuk diciptakan dibandingkan dengan rasa aman secara psikis. Untuk dapat menumbuhkan rasa aman, diperlukan sarana dan prasarana pendukung yang dapat menciptakan rasa aman tersebut.

Menurut Kamus Besar Bahasa Indonesia (KBBI) pagar adalah sesuatu yang digunakan untuk membatasi (mengelilingi, menyekat) pekarangan, tanah, rumah, kebun, dan sebagainya. Pagar merupakan elemen yang sangat penting dalam sebuah bangunan, bukan hanya sebagai pelengkap tampilan eksterior rumah tetapi juga telah menjadi sebuah kewajiban yang harus ada di setiap rumah. Pagar dapat membatasi pergerakan manusia, hewan atau membatasi rumah dari lingkungan sekitarnya, dengan adanya pagar maka privasi pemilih runah dapat lebih terjaga serta terhindar dari ancaman secara fisik maupun secara psikis.

Bluetooth adalah spesifikasi industri untuk jaringan kawasan pribadi (personal area networks atau PAN) tanpa kabel. Bluetooth menghubungkan dan dapat dipakai untuk melakukan tukar-menukar informasi diantara peralatan-peralatan. 
Spesifiksi dari peralatan Bluetooth ini dikembangkan dan didistribusikan oleh kelompok Bluetooth Special Interest Group. Saat ini perangkat Bluetooth telah banyak digunakan di banyak perangkat keras antara lain pada handphone, kamera digital, personal computer (PC), printer, headset. Bluetooth adalah teknologi komunikasi nirkabel yang beroperasi pada frekuensi 2,4 Ghz menggunakan transceiver frekuensi hopping yang mampu memberikan layanan komunikasi suara dan data real-time antara perangkat Bluetooth dengan jarak jangkauan terbatas $( \pm 10 \mathrm{M})$. Penggunaan Bluetooth dapat dilakukan dengan cara $\mathrm{PC}$ to $\mathrm{PC}$ file transfer, $\mathrm{PC}$ to $\mathrm{PC}$ synchonization, $\mathrm{PC}$ to PC mobile phone, wireless headseat dimana Bluetooth adalah suatu bentuk komunikasi data nirkabel berbasis frekuensi radio untuk menggantikan komunikasi serial yang berbasis kabel. Bluetooth terdiri dari dua jenis perangkat yaitu pemancar (transmitter) dan penerima (receiver). Walaupun komunikasi menggunakan Bluetooth memiliki kecepatan transfer data yang rendah tetapi tetap memiliki fitur-fitur keamanan sehingga dapat digunakan secara aman. Fitur-fitur yang disediakan Bluetooth antara lain : (1) Enkripsi data; (2) Autentikasi pengguna; (3) Lompatan frekuensi cepat (1600 hops/sec).

Saat ini hampir semua telpon seluler dilengkapi dengan sistem operasi berbasis Android. Android merupakan perangkat lunak (software) yang sistem operasinya berbasis linux dengan kode sumber terbuka (open source) yang di rancang untuk telpon seluler seperti tablet dan smartphone. Android pertama kali dikembangkan oleh Andy Rubin, Rich Milner, Nick Sears dan Chris White pada tahun 2003 di Android inc. Pada tahun 2005 Android inc dibeli oleh Google yang selanjutnya mengembangkan aplikasi tersebut untuk berbagai keperluan. Saat ini sistem Android juga digunakan pada mobil, tv, kamera, jam tangan dan perangkat lainya hal ini disebabkan karena sistem Android merupakan sistem operasi yang dapat disesuaikan dan mudah digunakan. Android secara komersial diperkenalkan pertama kali tanggal 20 Oktober 2008 pada smartphone HTC Dream.

Untuk dapat membuat program Android diperlukan program aplikasi, di dalam penelitian ini program aplikasi yang digunakan adalah App Invertor. App Inventor adalah alat tool untuk membangun software Android, aplikasi ini berbasis visual block programming, sehingga tidak diperlukan kode apapun untuk membuat perangkat lunak untuk Android selain itu paplikasi ini mudh digunakan dan tidak memerlukan keahlian khusus. [Menurut Mulyadi, ST tahun 2011]. App Inventor adalah aplikasi web open source awalnya dikembangkan oleh Google, dan saat ini dikelola oleh Massachusetts Institute of Technology (MIT). App Inventor memungkinkan pengguna baru untuk memprogram komputer untuk membuat aplikasi perangkat lunak untuk sistem operasi Android. App Inventor menggunakan antarmuka grafis, serupa dengan antarmuka pengguna di Scratch dan Star Logo TNG, yang memungkinkan pengguna untuk menarik dan melepaskan visual untuk membuat aplikasi yang mampu berjalan di perangkat Android.

Untuk dapat membuka pintu dan menutup pintu secara otomatis diperlukan sebuah perangkat pengontrol. Perangkat pengontrol pada penelitian ini menggunakan Arduino. Arduino merupakan pengendali mikro single-board yang bersifat open source yang diturunkan dari Wiring platform. Arduino dirancang untuk memudahkan penggunaan elektronik dalam berbagai bidang. Penggerak utama dari Arduino adalah mikprosesor Atmel AVR dan perangkat lunaknya memiliki bahasa pemrograman sendiri yang memiliki kemiripan syntax dengan bahasa pemrograman C. Untuk fleksibilitas, program dimasukkan melalui bootloader meskipun ada opsi untuk mem-bypass 
bootloader dan menggunakan pengunduh untuk memprogram microcontroler secara langsung melalui port ISP.

\section{METODE PENELITIAN}

Jenis penelitian adalah penelitian terapan dengan metode eksperimental dimana penulis merancang, membuat dan menguji coba aplikasi untuk melihat keefektifan dari apliasi tersebut, langkahlangkah dalam penelitian ini adalah

1. Perancangan sistem

2. Uji coba

3. Implementasi

Proses perancangan sistem merupakan proses studi literatur untuk menentukan bentuk aplikasi yang akan dibuat, pembuatan blok diagran dan gambar skematik untuk menentukan komponen yang akan digunakan. Proses uji coba adalah proses pengujian gambar skematik pada aplikasi simulasi yang pada penelitian ini menggunakan aplikasi proteus untuk melihat kelayakan dari rancangan sedangkan proses implementasi merupakan proses pembuatan prototipe dan uji coba prototipe.

\section{HASIL DAN PEMBAHASAN}

\section{Perancangan Sistem}

Dari hasil studi literatur, untuk medapat membuat perangkat yang dapat membuka dan menutup pintu pagar diperlukan komponen sesuai dengan gambar blok diagram yang ditunjukkan oleh gambar 1. Komponen yang diperlukan terdiri dari dua bagian yaitu komponen yang terletak di konstruksi pagar yaitu Arduino, Penerima Bluetooth, driver motor dan motor, sedangkan komponen yang tidak berada di konstruksi pagar adalah handphone.

Arduino merupakan penggerak utama yang akan menerima perintah dari handphone melalui penerima Bluetooth, perintah yang diterima akan diolah dan selanjutkan akan membuka atau menutup pintu sesuai dengan perintah yang diterima. Pada penelitian ini Arduino yang digunakan adalah Arduino uno, Bluetooth tipe HC-06 sedangkankan driver motor menggunakan ULN 2003 dan motor stepper dengan kode 28BYJ-48 dan komponen pendukung lain seperti resistor, kapasitor serta catu daya.

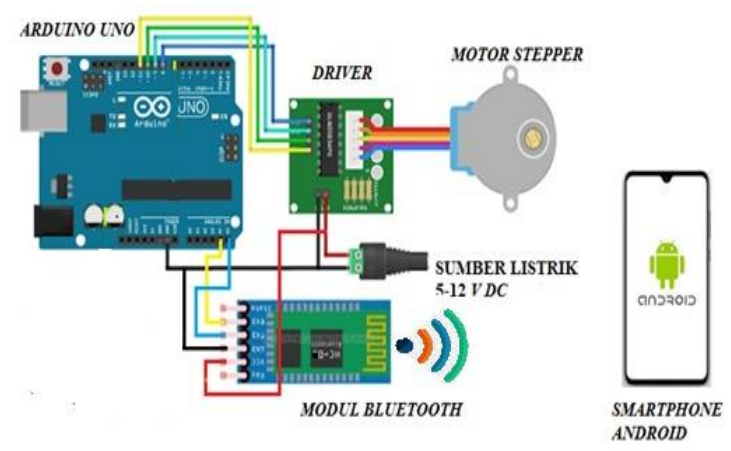

Gambar 1. Blok Diagram

Untuk melihat hubungan setiap komponen diperlukan gambar skematik. Gambar skematik penelitian ini seperti gambar 2.

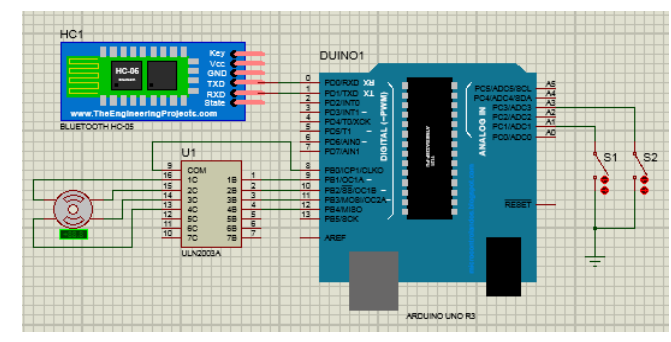

Gambar 2. Gambar Skematik

Dari gambar 2 dapat dilihat hubungan antara komponen-komponen dan nomor pin yang digunakan untuk menghubungkan setiap komponen tersebut. Bluetooth menggunakan hubungan koneksi serial maka dihubungkan ke pin D0 dan D1 Arduino sedangkan driver motor dihubungkan ke D8 sampai dengan D11 Arduino.

\section{Uji Coba}

Sebelum prototipe di buat perlu dilakukan ujicoba gambar skematik menggunakan program simulasi untuk 
melihat apakah disain yang dibuat dapat berjalan dengan baik. Pada penelitian ini simulasi menggunakan aplikasi proteus 8. Hasil simulasi menunjukkan bahwa rancangan dan program pada Arduino berjalan dengan baik. Gambar simulasi proteus seperti gambar 3 .

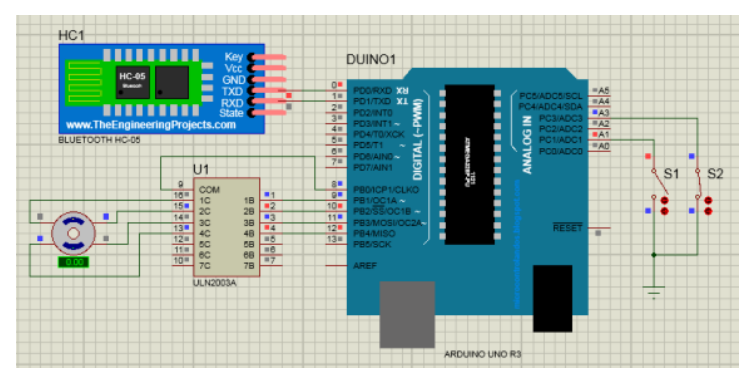

Gambar 3. Uji Coba

Gambar 4 menunjukkan program uji coba untuk membuka dan menutup pintu sedangkan gambar 5 menunjukkan program Android untuk membuka dan menutup pintu.

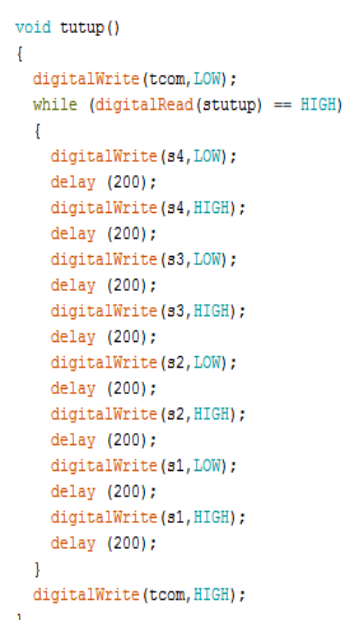

Gambar 4. Program Untuk Arduino

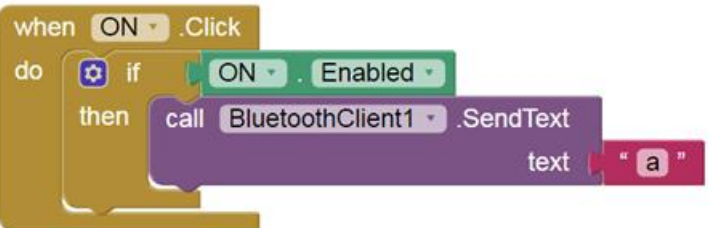

Gambar 5. Program Untuk Android

3. Implementasi

Implementasi merupakan sebuah proses pembuatan prototipe dari rancangan yang telah diujicoba sebelumnya. Prototipe dan unjuk kerja pengendali pagar menggunakan Android seperti gambar 6 dan 7 .

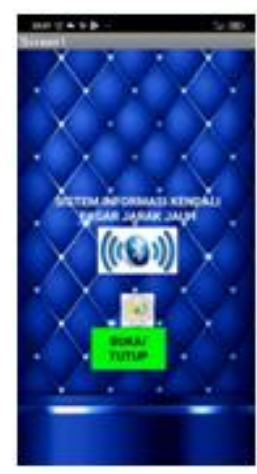

Gambar 4. Program Android

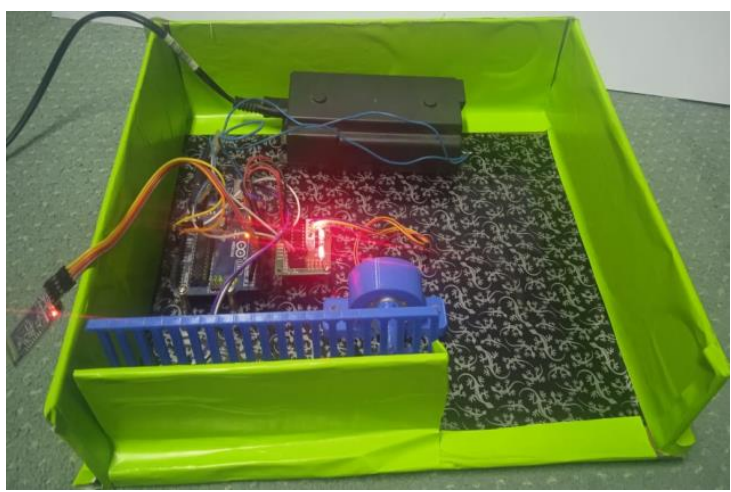

Gambar 5. Prototipe

Hasil unjuk kerja jarak steksi Bluetooth dapat dilihat pada tabel 1 .

Tabel 1. Unjuk Kerja

\begin{tabular}{ccc}
\hline Jarak(M) & Waktu(s) & Koneksi \\
\hline 1 & 0,5 & Konek \\
3 & 0,5 & Konek \\
5 & 0,5 & Konek \\
7 & 0,7 & Konek \\
9 & 1 & Konek \\
11 & 1 & Konek \\
13 & 1 & Konek \\
15 & 1,4 & Konek \\
17 & 1,5 & Konek \\
19 & 1,5 & Konek \\
21 & 1,5 & Konek \\
23 & 1,5 & Konek \\
25 & 1,5 & Konek \\
$>25$ & - & Tdk Konek \\
\hline
\end{tabular}




\section{KESIMPULAN}

Rasa aman fisik maupun psikis merupakan kebutuhan dasar bagi manusia dan setiap manusia berupaya untuk mendapatkan rasa aman tersebut. Pagar rumah merupakan pembatas antara penghuni rumah dengan lingkungan sekitarnya dengan adanya pagar maka manusia telah berupaya untuk meminimalisir terjadinya tindakan yang dapat menggangu rasa aman. Pagar yang digerakkan secara manual dengan mudah dapat dibuka oleh orang lain dengan menambahkan rangkaian elektronik hanya orang tertentu saja yang dapat membuka pagar tersebut sehingga keamanannya dapat ditingkatkan. Selain itu dari hasil uji coba menunjukkan bahwa sensitifitas sensor mencapai 25 meter yang berarti bahwa untuk membuka dan menutup pagar tidak perlu bersentuhan langsung dengan pagar hal ini dapat mengurangi resiko kecelakaan akibat pagar.

\section{DAFTAR PUSTAKA}

Maslow, A.H. (1943). "A theory of human motivation". Psychological Review. 50 (4): $\quad 370-96 . \quad$ CiteSeerX 10.1.1.334.7586. doi:10.1037/h0054346.

https://kbbi.web.id/pagar

https://id.wikipedia.org/wiki/ Bluetooth

https://www.olimex.com/Products/ /RF /BLUETOOTH-SERIAL-HC-

06/resources / hc06.pdf

Bluetooth-Wikipedia bahasa Indonesia, ensiklopedia bebas.html

Android - Wikipedia bahasa Indonesia, ensiklopedia bebas.html

http://Sejarah Android Dan Perkembangannya Lengkap Dari Awal Hingga Sekarang.html
http://Apa Itu Android, Sejarah dan Versiversinya.html

Google Developer Training Team, "Andriod Developer Fundamentals Course, learn to develop Android Applications" 2016.

Murphy Mark L. Beginning Android 2, Apress, America. 2010

Hartman, R., Rokitta, C., \& Peake, D. Oracle Application Express for Mobile Web Applications. Apress. 2013.

https://id.wikipedia.org/wiki/App_Inv entor.

Arduino - Wikipedia bahasa Indonesia, ensiklopedia bebas.html

Massimo Banzi, Michael Shiloh, "Getting Started with Arduino"

http://jptk.ppj.unp.ac.id/index.php/jptk/arti cle/view/66 